\title{
MISCELLANEOUS.
}

\section{Description of a new Species of Humming-bird of the Genus} Chrysolampis, By D. G. Eulior, F.L.S., F.Z.S., \&e.

Chrysolampis chlorolcema, sp. nov.

Top of head and nape of neck light metallic green, in some lights purplish; a black band across the back; rest of back and upper tail-coverts green, the longest blackish ; primaries purplish brown; tail fiery copper-colour, all the feathers margined with blackish purple; throat beautiful metallic emerald-greon; underparts black; flanks white; under tail-coverts rich chestnut, coppercolour in some lights; basal portions black; under wing-coverts green; bill black.

Length 4 inches, beak $0 \cdot 65$, wing $2 \cdot 4$, tail $1 \cdot 3$.

Hab. New Granada?

'This very interesting and handsome bird appears to be a second species of Chrysolampis, so long represented by the well-known $C$. moschitus, or Ruby-and-Topaz Hummer, which has for many years been employed for hat-decorations \&c., and is a well-known article of commerce. The present species does not at all resemble its relative as regards the colour of its plumage, inclining more to the genus Lampornis, among whose members, however, it cannot be included, for structural reasons. The specimen, which is unique, was received in a large collection of Hummers from New Granada; but I am unable to give its exact habitat.

\section{Axos Cliftoni. By Dr. J. E. Gray, F.R.S.}

Dr. Perceval Wright and Mr. Kent inform me that in examining some of the bark of the sponge from Nicol's Bay, which I described in the September Number (p. 272), and the slide of spicules which Mr. Clifton sent to me, they observed a very few of the double threerayed stars which Dr. Bowerbank figured in the 'British Sponges' (fig. 197), and which I had named Axos Cliftoni; so that I have no doubt that Echinospongia austratis and Axos Cliftoni are the same sponge. The spicules figured are exceptional forms, and seem to be imperfectly developed specimens of the hexradiate cubical spicules I have described, and which seem the characteristic spicules of the group.

Note on the Branched Variety of Squamulina scopula. By H. J. CARter, F.R.S. \&c.

With reference to my description and illustrations of Squamulina scopula, published in the 'Annals' of May last (vol. v. p. 309, pls. 4 $\& 5$ ), and my subsequent communication ( $i b$. p. 389 ), I am now in a position to afford positive evidence, from my own observation, on two conjectural points contained in the former-viz., first, that of Squamulina scopula being a foraminiferous animal, and, secondly, that Dr. Bowerbank's Haliphysema ramulosa (Brit. Spong. vol. ii. 
p. 79) is but a branched species (I should haro stated "variety") of Squamulina scopula.

I have just now found several specimens of the branched form of Squamulina scopula on the rocks here (Budleigh-Salterton, Devon), growing among sponges \&c. far above low-water mark, so that they are uncovered there twice every day for two or three hours at a time.

It is generally dichotomous, but by no means always so. The most perfect and largest specimen I have has eight heads. Its total length is about $2 \frac{1}{2}$ twelfths of an inch, the stem before branching being $1 \frac{1}{2}$, and the branched portion 1 line long by $1 \frac{1}{2}$ line broad in the spread. Thus it has undergone division three times.

On cutting off the branched head with a pair of scissors a.cross the main stem, and placing it in a watch-glass of sea-water (into which the specimen had been put on the piece of rock on which it grew, immediately on being broken off), the truncated end soon after threw out a bunch of obliquely branching and anastomosing filaments or pseudopodia, to the extent of 1-60th of an inch long, all round, which continued retracting and extending themselves and exhibiting the granule-circulation, after the manner of the sarcode of the Foraminifera, for six hours, when the whole were gradually withdrawn and did not reappear.

Thus the foraminiferous character of Squamulina scopula and its branched variety (which is precisely like it, with the exception of the branehing) is proved.

I could not see any filaments projected from the heads in any of the specimens; nor would it be easy to do so, as these probably entwine themselves about the spicules which are always raised up from the bottom in the water; but the truncated end of the stem lay on the watch-glass, over which it was easy to see the extended filaments with a one-inch compound power.

Specimens, of course, which grow on the rocks, exposed to all the fury of the waves, are not so perfect in their spicular element as those which grow in deep and more or less still water. But the wonder is how such delicate little creatures can grow at all in such turbulent situations.

\section{On two Species of Land-Planariæ from Borneo.}

To the Editors of the Annals and Magazine of Natural History.

Gentuener,-The figures and descriptions of the Turbellarians given by the Rev. W. Houghton in your last Number point them out as belonging to the genus Bipalium of Stimpson (Sphyrocephalus of Schmarda and Dunlopea of E. P. Wright in a former Number of the Annals). They are rather common forms in tropical regions. An account of their structure has been published by Schmarda, and also by M. Claparede. Their anatomy has been investigated by the writer in relation to their homologies with the Nemerteans.

September 23, 1870 .

I am, yours, \&c.,

W. C. M.Intosh. 